University

Adam Smith

Business School

WORKING

PAPER

SERIES

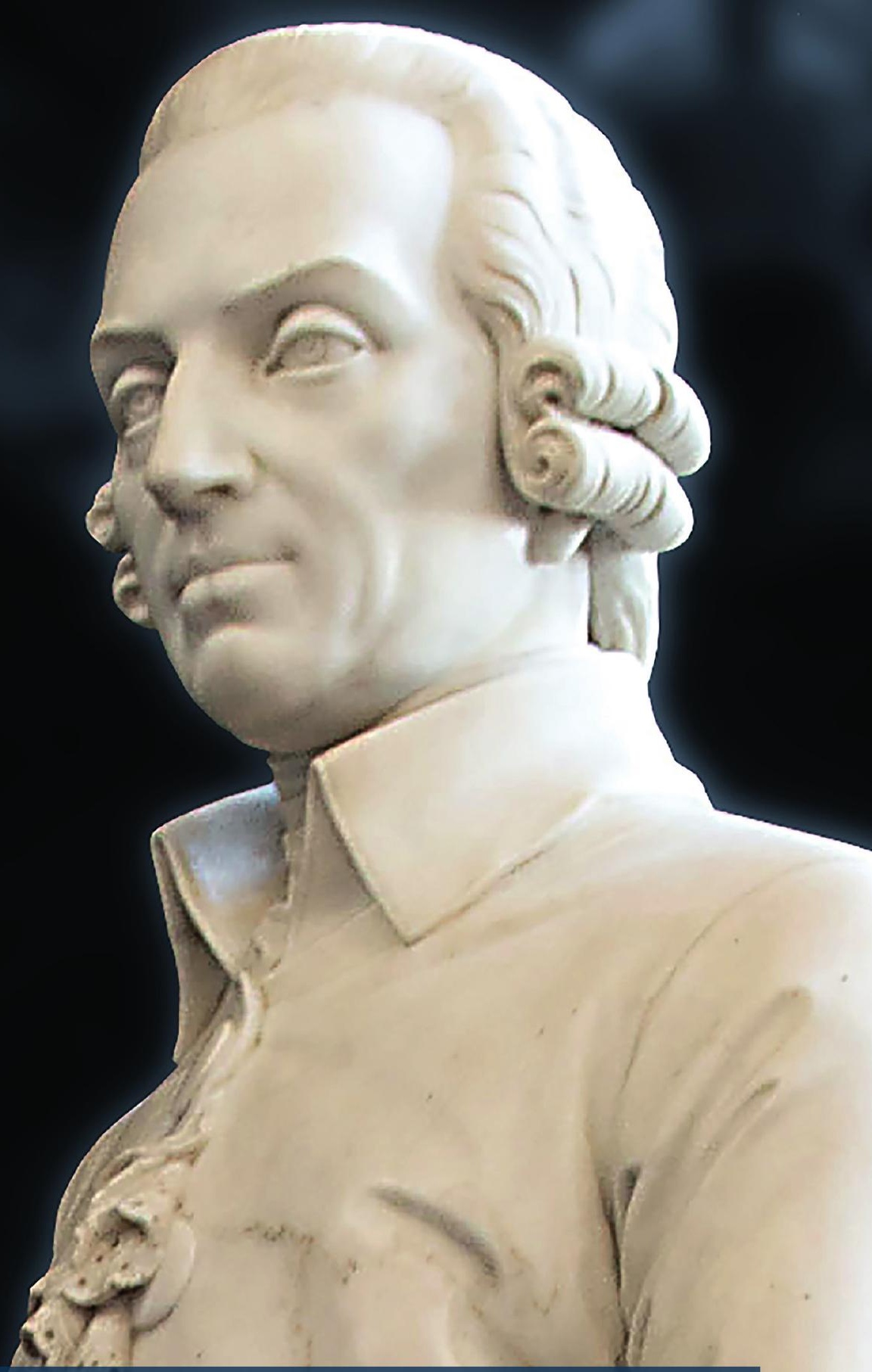

Heterogeneous Wealth Effects

Dimitris Christelis, Dimitris Georgarakos, Tullio Jappelli, Luigi Pistaferri and Maarten van Rooij

Paper no. 2020-20 September 2020 


\title{
Heterogeneous Wealth Effects ${ }^{\#}$
}

\author{
Dimitris Christelis, Dimitris Georgarakos, Tullio Jappelli, \\ Luigi Pistaferri, Maarten van Rooij
}

September 10, 2020

\begin{abstract}
We measure wealth effects on consumption using a novel research design: responses to direct survey questions asking how much a household would change consumption in response to unexpected (positive and negative) shocks to own home value. The average wealth effect is in the $2-5 \%$ range, in line with econometric estimates that associate changes in housing wealth with consumption realizations. However, our analysis uncovers significant heterogeneity. Extensive margin responses are limited: more than $90 \%$ of the sample reports no consumption adjustment to wealth shocks. On the other hand, conditioning on adjusting, intensive margin responses are substantial. Finally, the consumption response to positive wealth shocks is greater than the response to negative shocks.
\end{abstract}

JEL Classifications: D12, D14, E21

Keywords: Wealth Effect, Housing, Heterogeneity

\footnotetext{
\# Tullio Jappelli acknowledges financial support from the Italian Ministry of University and Research (PRIN Grant No. 2017RHFXK4). The opinions expressed in the paper are those of the authors and do not necessarily reflect the views of the European Central Bank or of De Nederlandsche Bank.

Christelis: University of Glasgow, CSEF, CFS, and Netspar; Georgarakos: European Central Bank and CFS; Jappelli: University of Naples Federico II, CSEF and CEPR; Pistaferri: Stanford University, SIEPR, NBER and CEPR; Van Rooij: De Nederlandsche Bank and Netspar
} 


\section{Introduction}

Housing is by far the most important asset in households' portfolios. As a result, the considerable volatility in house prices that many economies have recently experienced should have important implications for household spending. Spending responses are also likely to be heterogeneous across households and might differ between housing booms and busts.

Recent literature uses direct survey questions to elicit information about the consumption responses to scenarios involving positive and negative transitory income shocks (see, e.g., Christelis et al., 2019; Fuster et al., 2018). The approach is useful, as it provides householdspecific estimates of the marginal propensity to consume (MPC) out of possible income changes. This allows associating MPC responses of each household with observables such as household resources and comparing MPCs out of income shocks of different sign.

The present paper builds on this literature using direct survey questions that allow estimating the impact of housing wealth shocks on households' expenditures (or "wealth effect”, in short). It makes four contributions. It takes advantage of the first (to the best of our knowledge) population-representative household survey providing consumption responses to alternative scenarios of idiosyncratic housing wealth shocks. Most of the literature so far has focused on the consumption effect of income shocks and ignored wealth shocks. ${ }^{1}$ Besides being the largest asset in household portfolios, housing is also illiquid and infrequently traded and has both a consumption and an investment component. Thus, it is instructive to directly measure homeowners' consumption response to possible shocks to the value of their own house by explicitly asking about it. This can be useful for estimating the consumer spending drop due to a housing bust, an important policy exercise in light of the recent Great Recession.

\footnotetext{
${ }^{1}$ See Shapiro and Slemrod (1995; 2003); Jappelli and Pistaferri (2014); Graziani et al. (2016); Christelis et al. (2019); Fuster et al. (2018).
} 
Our second contribution is more conceptual. In principle, a wealth effect should measure the response of consumption to exogenous changes in asset prices However, in practice, consumption may spuriously respond to endogenous changes in home value (i.e., households buy new furniture when renovating their homes). ${ }^{2}$ In addition, behavioural traits may correlate with housing values reported in surveys making hard to identify the effect of a wealth shock on spending. For example, individuals with optimistic economic outlooks are likely to report larger (smaller) increases (declines) in their housing values due to a given shock, compared to pessimistic individuals. More generally, a multitude of factors can contribute to the observed co-movements of spending and home prices. By using direct survey questions asking about house price shocks, we bypass the problem of distinguishing between exogenous (i.e., house price changes due to local housing conditions or labor market shocks) and endogenous (i.e., renovations, unit splits, etc.) movements in home values which plague most of the empirical literature using realized consumption and house value data. Moreover, given that all respondents in our survey face the same shock scenarios, the shocks are, by design, orthogonal to household behavioural traits and other unobserved characteristics. ${ }^{3}$

The third contribution regards the analysis of heterogeneous wealth effects, as our approach elicits consumption responses to housing wealth shocks that are household-specific. We associate such heterogeneity in consumption responses to cash-on-hand, loan-to-value ratio (LTV), age and other demographic variables, and examine whether these associations are

\footnotetext{
${ }^{2}$ Carroll et al. (2011) point out that identifying the "pure” housing wealth effect is hard, because "one would want data on spending by individual households before and after some truly exogenous change in their house values, caused for example by the unexpected discovery of neighborhood sources of pollution.” A similar problem arises in the analysis of the link between consumption and stock market wealth. Dynan and Maki (2001) distinguish changes in wealth that directly cause changes in consumption through their effect on households' contemporaneous budget sets, from situations in which changes in wealth predict changes in consumption because they signal changes in future income.

${ }^{3}$ In the robustness section, we discuss extensive evidence on this, as responses to our survey questions are invariant to a multitude of factors, including individuals' general optimism, understanding of the survey questions and expectations about future house price shocks (aggregate or idiosyncratic).
} 
consistent with existing models of consumption behavior. Hence, we shed some light on the channels through which unanticipated housing wealth shocks induce consumption adjustments.

Finally, we test for asymmetric responses to positive versus negative housing price shocks. As is the case with income shocks, it is instructive to investigate whether consumption responds asymmetrically to wealth shocks of different signs. As we discuss, this asymmetry can provide insights about the role of liquidity constraints and about the impact of policies affecting house values (such as changes in the maximum allowed LTV ratio or property taxes).

We design a special module for a representative survey of Dutch households. The module includes questions on how respondents would change their consumption in response to an unexpected and permanent increase or decrease in their housing wealth corresponding to $10 \%$ of their current house value. As discussed in detail below, we conduct several validation checks to assess the quality of our special-purpose survey. The survey shows that among homeowners the average wealth effect is $4.7 \%$ for a housing price increase and $2.1 \%$ for a housing price decline. These values are broadly in line with econometric estimates that use actual housing wealth and consumption data.

The key empirical finding made possible by our research design is that there is significant heterogeneity in wealth effects, with over $90 \%$ of homeowners reporting no reaction to either positive or negative shocks. To the best of our knowledge, this is a novel finding in the literature on the consumption response to housing wealth shocks. For households who do react to the wealth shock, an important question is how they finance the change in consumption, given that housing wealth is illiquid and indivisible. We find that reducing savings or using current income (in the case of a positive housing wealth shock) or increasing saving (in the case of a negative wealth shock) are the typical strategies followed by households.

In line with predictions of models with precautionary saving and liquidity constraints, we find a negative association between the wealth effect and cash-on-hand. This is supported both 
by descriptive and by more formal regression analyses. We also examine whether households with different levels of debt also differ in their consumption response to housing wealth shocks. We find evidence that homeowners with high LTV ratios are particularly responsive to negative shocks. This is, as we shall discuss, consistent with the institutional environment of the Netherlands, where underwater households are limited in their residential mobility choices and may face difficulties in getting additional credit.

Last, we find that the consumption response to positive wealth shocks is greater than the response to negative shocks. As pointed out by Andersen and Leth-Petersen (2020), an asymmetric wealth effect is consistent with a collateral channel mechanism. According to this, increases in home values allow additional borrowing and spending, while decreases in home values do not necessarily require households to reduce borrowing given that the constraint binds only at the time of loan origination.

The paper is organized as follows. Section 2 discusses the economic motivation and empirical evidence on the microeconomic estimates of the wealth effect. Section 3 describes the survey design and discusses several validation checks and survey features that lend credibility to our analysis. Section 4 discusses the descriptive analysis and the regression results relating the wealth effects of consumption to household socio-economic characteristics, along with some robustness checks. Section 5 concludes.

\section{Motivation and micro evidence}

Most literature estimating the consumption effect of a change in house prices relies on two implicit assumptions. ${ }^{4}$ First, consumers don’t anticipate these wealth shocks. Second, current house prices are the best predictors of future ones; hence, consumers view any house value

\footnotetext{
${ }^{4}$ We focus here only on shocks to housing wealth, which may be hard to monetize due to the illiquidity and indivisibility of the asset. In contrast, shocks arising from changes in the values of financial assets are more easily converted into cash.
} 
changes as highly persistent. Under these assumptions, the life-cycle permanent income model suggests that unexpected changes in housing wealth affect the consumption of homeowners by an amount equivalent to the annuity value of the shock. ${ }^{5}$ On the other hand, the value of the housing services homeowners consume increases commensurately, and thus it is not clear to what extent the consumption of other goods and services should be affected by the increase in the home value.

In addition to this "pure” wealth effect, a change in house prices can affect consumption through a liquidity effect, since housing wealth can be used as collateral. A positive shock on housing wealth attenuates borrowing constraints and the need for precautionary saving, stimulating consumption. Conversely, a house price drop reduces the ability to borrow, and increases the need for precautionary saving due to a reduced future ability to borrow (needed if, e.g., there is a negative future income shock). Both effects should reduce current consumption.

As noted by Andersen and Leth-Petersen (2020), a comparison of wealth shocks of different sign can help disentangle the pure wealth effect from the collateral channel. For unconstrained households the response should be symmetric for positive and negative price changes. For constrained households the increase in home values offers the possibility for additional borrowing that can be used to finance spending. However, a decrease in home values does not necessarily require households to reduce borrowing, because the constraint binds at the time of loan origination. The collateral effect therefore implies a stronger response of consumption to positive wealth shocks than to negative ones.

\footnotetext{
${ }^{5}$ In a theoretical paper, Berger et al. (2018) analyze the various channels through which house price shocks affect consumption. They show that the consumption effect of a permanent house price shock equals the marginal propensity to consume out of a temporary income shock, and that consumption responses depend on the level and distribution of debt, the size and history of house price shocks, and credit supply.
} 
The wealth effect might also differ by the level of cash-on-hand. When hit by a negative shock, households with low cash-on-hand are more likely to reduce consumption than those with high cash-on-hand, given that the latter can draw on accumulated savings. Moreover, a drop in the house value should make it more difficult to borrow to smooth consumption using the house as collateral, thus worsening the liquidity problem of those with low cash-on-hand. One should therefore expect a negative correlation between cash-on-hand and the wealth effect on consumption arising from negative wealth shocks.

A positive wealth shock, however, makes households with high cash-on-hand increase their consumption by drawing on existing savings, while cash-poor consumers are able to increase consumption only by borrowing (using the appreciated house as collateral) or by selling the house outright (to lock-in their capital gain). In other words, the positive wealth shock likely alleviates borrowing constraints of cash-poor households. This should in turn favor pent-up consumption, as it can enable these households to increase their spending by an amount large enough to match what they would have spent under no borrowing constraints. Hence, the relation between the wealth effect and cash-on-hand from positive wealth shocks is ambiguous and depends on whether the positive shock allows households with low cash-on-hand to borrow or sell the house.

Given the different links between house prices and consumption, it is perhaps not surprising that from an empirical point of view it is difficult to pin down the wealth effect and that there is considerable disagreement over its magnitude. In the U.K., Disney et al. (2010) find a low wealth effect (of the order of 1 percent), whereas Campbell and Cocco (2007) report a strong response for older owners. Attanasio et al. (2009) conclude instead that the comovements in U.K. consumption and house prices reflect not a causal link but the action of common factors, contradicting the findings of Campbell and Cocco (2007). 
In an influential paper, Mian et al. (2013) find a housing wealth effect in the U.S. in the order of 5-7 percent, and that areas with poorer and more levered households display a significantly higher wealth effect. Christelis et al. (2015) examine the effects of the recent crises in the US housing market on household spending, using micro data from the 2009 Internet survey of the Health and Retirement Study. They focus on negative and exogenous wealth changes and find a housing wealth effect of only 1 percent. They also find that consumption responds more strongly to permanent shocks than to shocks perceived as transitory. Aladangady (2017) finds a wealth effect of 4.7 cents on the dollar for homeowners, but a negligible response for renters. Most papers find larger responses among credit constrained households, suggesting that the loosening of borrowing constraints is a primary driver of the housing wealth effect (see also Contreras and Nichols, 2010, for a comprehensive survey of the literature).

Estimates of the wealth effects for countries other than the UK or the US are more nuanced, possibly owing to institutional differences. Using a large panel of Danish households, Browning et al. (2013) find little evidence of a housing wealth effect. On the other hand, Zhang (2019), using a panel of Dutch households finds wealth effects in the order of 7 cents for owners, but negligible responses for renters. ${ }^{6}$ Paiella and Pistaferri (2017) use the Italian Survey of Household Income and Wealth which contains data on subjective interest rate expectations to isolate exogenous changes in wealth (due only to asset price shocks) from anticipated changes (due to, for example, planned portfolio rebalancing). They estimate an overall wealth effect of about 3 cents per (unexpected) euro increase in wealth, primarily driven by changes in housing prices. ${ }^{7}$ In a recent paper, Andersen and Leth-Petersen (2020) elicit

\footnotetext{
${ }^{6}$ In the context of Dutch economy, Ji et al. (2019) explore the link between household debt and consumption. Using administrative data, they find that the consumption of highly indebted households decreased much more during the crisis than that of other households.

${ }^{7}$ Contrary to the predictions from the theory, they find that the consumption response to anticipated changes in wealth is also large and significant, of the same magnitude as the response to unanticipated changes. They also
} 
subjective expectations of future home value for a sample of Danish households, and find that unanticipated increase in home values lead to an increase in mortgage debt and spending of 35 percent of the unanticipated gain, but no effect from negative shocks, supporting the view that the wealth effect operates primarily through the collateral channel.

In sum, the review of the existing literature points to four key issues that new research should try to gain insights into. First, when estimating the wealth effect, applied research should address the issue that movements in asset prices are likely to be correlated with other shocks that may have a separate effect on consumption. Second, it is instructive to differentiate between anticipated and unanticipated changes in wealth (see Jappelli and Pistaferri, 2011, 2017 for a survey of the literature). Third, it is important to distinguish between positive and negative wealth shocks, as the possible asymmetric response with respect to these shocks can shed light on the relevance of the collateral channel. Fourth, one should expect that the wealth effect is heterogeneous, and therefore examine how it varies across different demographic groups.

One limitation of the existing studies is that the estimated wealth effect on consumption is an average of individual responses, which misses the possibility of response heterogeneity. Moreover, in real life households experience either a positive or a negative wealth shock. As a result, estimates of positive or negative wealth effects are hard to generalize as they depend, to a certain extent, on the characteristics of the selected sub-group of households that has experienced a given type of shock.

Against this background, for the first time in the related literature, instead of estimating an average household response to house price shocks, our survey records an unanticipated 10\% increase or decrease in one's home value. Therefore, we don’t face the challenge of trying to

find evidence that the wealth effect from negative price shocks is larger than that from positive shocks, consistent with the presence of liquidity constraints. 
disentangle the response of spending to the wealth shock from responses to other shocks, nor do we rely on selected household groups that have experienced only one type of shock (that is, either positive or negative). We are thus able to elicit a household-specific wealth effect on consumption out of positive and negative housing wealth shocks. Our measure can also be compared with aggregate estimates, used to test for possible asymmetric responses to shocks, and related to household resources, indebtedness and demographic variables.

Our research design builds on the contributions of Shapiro and Slemrod (1995, 2003), who pioneered the use of survey data to elicit qualitative responses to income shocks. Jappelli and Pistaferri (2014, 2020) refined the approach, considering quantitative responses to income shock scenarios, and providing quantitative estimates of the MPC from income shocks. In some recent contributions, Christelis et al. (2019) and Fuster et al. (2018) distinguish between positive and negative income shocks of different size. More generally, the paper fits in the broad literature advocating the use of subjective perceptions and expectations in macroeconomics (for a survey, see Manski, 2017).

\section{Survey design}

\subsection{The data}

We use data from the CentER Internet panel, a project sponsored by the Dutch National Bank and maintained by CentERdata at Tilburg University. The baseline survey, known as the DNB Household Survey (DHS), is conducted once a year via the Internet and collects detailed information on a range of demographics and asset holdings for a representative sample of Dutch-speaking households in the Netherlands. ${ }^{8}$ In addition to the baseline survey, households may be asked, during the year, to participate in special purpose surveys.

\footnotetext{
${ }^{8}$ To ensure representativeness of the CentER panel, households selected to participate are provided with an Internet connection if they fail to have one.
} 
We administered a special purpose survey in September 2018 to all adult members of the CentER Internet panel. The survey first asks homeowners to provide an estimate of the current value of their house. It then asks them to report how they would change their consumption of durable and non-durable goods in the next 12 months in response to an unexpected change in the value of their house. The question explicitly refers to a one-off, permanent increase (or decrease) in this value. Given the significant heterogeneity of the home value (due to geography, type of unit, and other idiosyncratic factors), we present respondents with wealth changes (expressed in euro) that correspond to $10 \%$ of their (self-assessed) home value. By tailoring the shock to household-specific home values, we avoid biasing responses by the size of the shock. ${ }^{9}$ Moreover, framing the question in a realistic context should increase the reliability of the consumption response. Finally, as the consumers provide a consumption change in euro, we can readily calculate an estimate of the wealth effect on consumption.

In more detail, we used the following question to elicit consumption responses to a positive wealth shock:

Suppose that the value of your house increases unexpectedly by YYY euro and that this increase in value of your house is permanent (that is, it lasts forever). In the next 12 months, how would you use this increase in the value of your house? (You can add a euro amount to item 1, item 2, or both).

1. Purchase non-durable goods and services (food, clothes, travel, vacation, entertainment, cosmetics, etc.) that you otherwise would not have purchased, namely an amount of $X X X$ euro;

\footnotetext{
${ }^{9}$ Presenting, instead, respondents with a fixed euro change in wealth would imply a very large (small) shock for households with relatively low (high) house value.
} 
2. Purchase durable goods (cars, home improvement, furniture, jewelry, etc.) that you otherwise would not have purchased or that you would have purchased later, namely an amount of XXX euro;

3. Would not spend more on durable and non-durable goods and services than you otherwise would do;

4. I don't know.

The question for a negative wealth shock has been phrased symmetrically: Imagine that the value of your house declines unexpectedly by YYY euro and that this reduction in value of your house is permanent (that is, it lasts forever). In the next 12 months, how would you react to this decrease in the value of your house?

1. Reduce spending on non-durable goods and services (food, clothes, travel, vacation, entertainment, cosmetics, etc.), namely an amount of XXX euro;

2. Cancel or postpone for later the purchase of durable goods (cars, home improvement, furniture, jewelry, etc.) that you otherwise would have purchased, namely an amount of XXX euro;

3. Would not spend less on durable and non-durable goods and services than you otherwise would do;

4. I don't know.

An advantage of our survey is that the same respondent replies to the questions on positive and negative shocks. To minimize framing problems, we randomly split the homeowner sample into two, and ask the first (second) group the positive (negative) shock question. Two weeks later, we ask the first group the negative shock question and vice versa.

In addition, we ask follow-up questions on how respondents would adjust consumption after a positive or negative shock. This allows distinguishing between the various possible 
channels through which housing wealth shocks might affect consumption. ${ }^{10}$ Although the questions ask about consumption of non-durables and durables separately, for most of the analysis we combine the two answers into one.

The survey is a cross-section of 1,264 homeowners. It also collects information on several background characteristics (demographics, consumption, income, house value, financial wealth and indebtedness) that are useful for our analysis.

Several features of the survey questions are noteworthy. First, all respondents reply to the same shock scenarios (scaled by the underlying housing value). Thus, the shocks are, by design, orthogonal to respondents' behavioural traits and other unobserved characteristics; as a result, we can consider our estimates of the effects of the shocks to have a causal interpretation. In contrast, changes in housing values recorded in surveys may correlate with respondents' unobservables (e.g. optimism) making harder to identify the effect of the shock on consumption changes.

Second, the survey questions refer to idiosyncratic ("the value of your house") rather than aggregate changes in housing prices. As Sinai and Souleles (2005) have pointed out, house prices are generally correlated, and owning a home is a hedge against fluctuations in housing costs. The Sinai and Souleles (2005) channel means that a household's response to a house price change should depend crucially on whether it is just the owner's house value that has changed (in which case the owner's real wealth is changing, as in our hypothetical question) or whether there is a boom or a bust, and all houses have changed in value (in which case real wealth is not necessarily changing).

\footnotetext{
${ }^{10}$ In the case of a positive shock, respondents are asked to indicate how they would finance the reported increase in spending by choosing at least one of the following options: (a) drawing from savings or using current income; (b) selling the house, to cash in the capital gain; (c) drawing funds from a (mortgage or home equity) loan, using the house as collateral; (d) other means. In case of a negative shock, respondents are asked to indicate how they would use the money that they subtract from spending by choosing at least one of the following options: (a) add to savings; (b) invest in home improvements; (c) pay-off some of their debts; (d) other uses.
} 
Third, respondents report by how much they would increase or cut spending "in the next 12 months”. A specific timeframe is important because it allows us to rule out that differences in the wealth effects on consumption arise from differences in the timing of planned spending. Of course, different adjustments in subsequent years cannot be ruled out. ${ }^{11}$ In principle, it would be useful to ask similar questions with other time horizons (e.g., how would consumption change in the second or later years after the shock) but this would considerably increase the questionnaire complexity.

Fourth, the questions provide quantitative metrics for the proposed scenarios, as opposed to questions eliciting qualitative information ("mostly save/ mostly spend") on how people spend a windfall, such as tax rebates. Although business cycle effects can never be ruled out, the period in which the survey was administered (September 2018) was a "normal" one, with GDP growing steadily at about $2.5 \%$ on an annual basis. Furthermore, as discussed below, our results are not affected by respondents’ expectations or uncertainty about future house prices.

Fifth, we focus on housing, as it is the largest component of wealth for most households. Moreover, direct survey questions do not easily distinguish changes in financial wealth due to market prices from changes due to active saving. ${ }^{12}$

Finally, note that a $10 \%$ permanent price change in the home value is non-trivial. In our sample, the mean (median) home value, among homeowners, is about 306,000 euro (250,000 euro). Our questions hence maximize the chance of observing a consumption response, as, due to possible adjustment costs, such a response is more likely to be observed when shocks are large. Indeed, it is possible that previous work has been unable to tightly estimate the wealth effect on consumption precisely because in reality most shocks are small.

\footnotetext{
${ }^{11}$ Carroll et al. (2011) show that the long-term effect of housing losses on consumption could be larger than the short-term one.

${ }^{12}$ Household financial portfolios are also quite heterogeneous, implying that a change in stock prices might affect considerably stockholders, but leave non-stockholders indifferent. Moreover, the same stock market portfolio may itself being differently diversified across households.
} 


\subsection{Validation checks and survey features}

As discussed above, using a household survey to elicit individual-specific spending responses to housing wealth shock scenarios has several advantages (such as allowing for response heterogeneity and avoiding selection on the sign of the wealth shock). Nonetheless, it is instructive to examine the quality of the survey and the assumption that reactions to shock scenarios are correlated with actual behavior. In what follows, we discuss several validation checks and survey features that lend credibility to our analysis.

A first check, allowing comparison of our analysis with previous literature, is to use our sample to replicate a typical wealth effect regression. For this purpose, we regress the growth rate of realized consumption on the growth rate of the home value in the past 12 months and on quartiles of lagged cash-on-hand. ${ }^{13}$ The estimated wealth effect coefficient is 0.17 with a standard error of 0.08. Evaluated at the sample mean (median) of the ratio of home value to consumption, the implied wealth effect out of house price changes is $1.3 \%(1 \%)$.

These values are at the low-end of the range of wealth effect estimates obtained with macro and micro data for the U.S. and discussed in Section 2. One weakness of this regression approach (besides endogeneity issues) is that it estimates an average effect. In the analysis below we show that the average of individual wealth effects elicited from the direct survey questions is in fact broadly aligned with the one estimated from the standard regression approach. However, as we shall see a similar mean masks non-negligible heterogeneity - with a large fraction of household not responding at all and a small fraction exhibiting very large responses to house price shocks.

\footnotetext{
${ }^{13}$ We recover the lagged value of cash-on-hand from the 2017 baseline DHS survey.
} 
One additional way to examine the validity of the directly elicited spending responses to our $10 \%$ unanticipated idiosyncratic shock questions is to check whether these spending responses are associated with households’ expectations about local house prices. As mentioned, the fact that all respondents face the same shock scenarios implies that these shocks are not affected by individual traits, including own expectations. Also, these scenarios refer to the owner's house and not to local house prices. If such an association existed, then it could be the case that spending measures in our survey were not necessarily due to the $10 \%$ unanticipated shock questions on own house (i.e., the scenario presented to respondents) but rather to households' own assessment of the housing market’s future prospects. To check this, we ask in our special survey a set of questions that elicit, for each respondent, the first and second moments of the expected distribution of house prices in their neighbourhood. ${ }^{14}$ We find that neither expectations about average future house prices nor the underlying expected uncertainty about them correlate with our reported spending responses. We thus conclude that our spending measures indeed represent responses to the $10 \%$ unanticipated shock questions and are not correlated with different outlooks about housing market prospects. ${ }^{15}$

A third check is based on the theoretical prediction that individuals who adjust consumption due to permanent wealth shocks should be also more likely to adjust consumption in response to transitory income shocks (see Berger et al., 2018). ${ }^{16}$ We obtain MPCs out of positive and negative transitory income shocks (equal to one month of household income) by asking our survey participants the same questions as in Christelis et al. (2019), who found that

\footnotetext{
14 Respondents report the minimum and maximum values in the following question: "Imagine you own an apartment worth $€ 100,000$ in the neighbourhood you currently live in. What do you think will be the value of this apartment in 12 months, if you decide to sell it?” Using a simple triangular distribution, we calculate the mean and variance for each respondent. Guiso, Jappelli and Pistaferri (2002) first used this method to elicit individualspecific expectations and uncertainty about future income.

${ }^{15}$ The same conclusion holds when we control for house price expectations at the national level that have a smaller idiosyncratic component compared to those regarding own neighbourhood.

16 They show that consumption responses to permanent house price shocks can be approximated by the marginal propensity to consume out of temporary income times the value of housing.
} 
elicited MPCs are broadly in line with models of intertemporal choice with precautionary saving, borrowing constraints, and finite horizons. We find that there is indeed a strong positive correlation between the individual MPCs out of transitory income shock and the wealth effects from permanent wealth shocks.

Besides the above validation checks, there are several survey features that are worth mentioning and make the Netherlands a suitable country for our analysis. First, about twothirds of the adult population are homeowners and thus can more easily conceptualize scenarios of appreciation or depreciation in housing values. ${ }^{17}$

Furthermore, homeowners likely have fairly accurate knowledge about changes in their own house value. Every year, municipalities assess the value of all houses falling under their property tax jurisdiction. Subsequently, municipalities send a notice of the assessed value to the homeowner for calculating the property tax. Importantly, this administrative value is updated every year based on housing transactions in the same area, giving most weight to nearby transactions. ${ }^{18}$ Additionally, households must report the assessed home value in their income tax form in order to calculate the imputed rent tax.

Given that in the Netherlands the cadastral value of the house is used for tax purposes, the housing shock scenarios also imply a tax change. Typically, the implied change in tax burden is small (in the order of about 100 euro per year), and hence it is unlikely to change behavior much relative to a case without tax implications. ${ }^{19}$ Hence, in our calculations of the wealth effects we assume that households ignore tax changes when responding.

\footnotetext{
17 This is partly due to the large volatility in house prices of the last decade: a housing bust in 2008-13 (when house prices declined by more than $20 \%$ ) was followed by a (still ongoing) housing boom.

${ }^{18}$ Likewise, mortgagors are typically aware of their outstanding mortgage amount, not only due to bank statements but also by having to report the outstanding mortgage amount in their tax declaration.

${ }^{19}$ The amount is calculated using the median reported house value (250,000 euro) and the average rates on three real estate-related taxes (i.e., the municipality tax, the flood management, and the tax on imputed rents).
} 


\section{Empirical results}

\subsection{Descriptive analysis}

Table 1 reports descriptive statistics on the respondents with non-missing data for consumption changes due to positive and negative wealth shocks. Other statistics refer to the whole sample. The fraction of households reporting that they would increase consumption in response to a positive shock is $8.4 \%$, while the fraction reporting that they would reduce consumption in response to a negative shock is $9.4 \%$.

One reason why most respondents report no consumption response may be that a home price change affects in the same direction also the value of housing services consumption (i.e., imputed rent). Hence, respondents may think that the shock has not materially changed their intertemporal budget constraint. On the other hand, when the shock is positive, liquidityconstrained households could still choose to increase their spending to approach their desired non-constrained spending. Another reason for consumption inertia could be adjustment costs affecting durables. Finally, the illiquidity and indivisibility of the house could make it difficult to translate a capital gain into actual spending through borrowing or selling.

Using information on the house price change, one can compute the wealth effect on consumption for each homeowner for both positive and negative shocks. The sample averages of these wealth effects are $4.7 \%$ for positive shocks, and $2.1 \%$ for negative shocks. As discussed in Section 2, these estimates of the wealth effects are in line with existing ones derived from micro-level and aggregate data. Nevertheless, these average responses hide vast heterogeneity, with most homeowners reporting that they would not react to house price changes, and a minority reporting both an extensive margin and a substantial intensive margin response.

This reported wealth effect heterogeneity implies that for those who adjust consumption, the adjustment is considerable, with an average wealth effect equal to $56 \%$ for positive shocks 
and $21 \%$ for negative ones. Furthermore, most of the adjustment refers to durable goods that people plan to buy in case of positive shocks or postpone purchasing in case of negative shocks.

Financial market frictions (e.g., inability to access products like home equity loans) may induce asymmetries in the consumption response to positive and negative shocks. For example, when households cannot borrow to increase their consumption and have little liquid wealth, they will not respond to house price increases. In contrast, they may still reduce consumption when a negative permanent wealth shock occurs (since the future liquidation value of the asset has declined and consumption needs to be adjusted accordingly).

When testing the equality between the mean responses to positive and negative shocks, the average wealth effect from positive shocks exceeds that of negative ones at the $1 \%$ confidence level. This holds for both unconditional and conditional (i.e., on a non-zero response) mean responses.

The larger response of consumption to positive shocks is consistent with the collateral channel view, that is, the hypothesis that increases in home values allow additional borrowing and spending, while decreases in home values do not necessarily require households to reduce borrowing, as found by Andersen and Leth-Petersen (2020).

Our survey contains follow-up questions that shed light on the various channels through which unanticipated changes in housing wealth might increase consumption. Indeed, we find that a non-negligible fraction of households reports that they would use their house as collateral in order to "monetize" an unexpected house value increase. In particular, of those reporting a positive consumption change, the majority (65\%) report that they would draw from their savings or use current income; $26 \%$ that they would top-up their mortgage, using their house as collateral; and $20 \%$ that they would sell the house to cash the increase in home value. ${ }^{20}$ Note

\footnotetext{
${ }^{20}$ While this may seem a large number, it may also reflect the decision to sell a house earlier than planned (i.e., a pure intertemporal effect).
} 
that the survey allows for multiple answers, so the fractions do not sum to 1 . The latter two responses indicate the presence of liquidity constraints that households try to alleviate by increased borrowing or by selling the house to lock in the capital gains.

On the other hand, of those reporting that they would reduce consumption in response to a negative shock, 55\% mentions that they would increase savings; $51 \%$ that they would pay off some of their debts; and $21 \%$ that they would use the money that is not spent on consumption to invest in home improvements.

This evidence suggests that drawing from one's savings represents the main channel through which housing wealth shocks induce consumption adjustments. This is in contrast with evidence from the US, where the mortgage refinancing channel has been shown to play a dominant role (see recent contributions by Berger et al. (2018) and Beraja et al. (2019)). One possible reason for these differences is that home equity extraction is more costly in the Netherlands than in the US. Loan refinancing requires the payment of a penalty fee, except when the house is sold, or the interest rate period is upon maturity. Additional transaction fees apply if refinancing or equity extraction result in a larger loan size. Homeowners also face costs for mortgage advice, origination fees, appraisal costs and notary fees when they switch to a lender offering more competitive mortgage terms. Finally, while the interest payments on the original mortgage are tax-deductible, the interests on additional loan amounts that originate from refinancing or equity extraction are not (except if used for home improvements). ${ }^{21}$

The upper-left panel of Figure 1 shows the relation between log cash-on-hand (grouped into 20 equally sized bins) and the wealth effect out of positive shocks. We define cash-onhand as the sum of household net income and financial wealth, net of consumer debt. An

\footnotetext{
${ }^{21}$ Some other features of the Dutch mortgage market are worth mentioning. The Netherlands is among the countries with the highest national mortgage debt worldwide and almost ninety percent of homeowners take up a mortgage. Mortgage lenders do not usually require a down payment. The typical duration of a mortgage is 30 years. Many mortgage loans have interest rates fixed for 5, 10 or 20 years, while adjustable rate mortgages are uncommon.
} 
additional reason for adopting this definition is that households likely face high transaction costs from selling illiquid assets. ${ }^{22}$

The figure suggests a negative association between the wealth effect from positive shocks and cash-on-hand. While below median cash-on-hand the wealth effect is between 5 and 10 cents per euro, in the top percentiles it is close to zero, with almost no household adjusting consumption in response to the shock. Instead, looking at the top right panel, we find no clear pattern between the wealth effect from negative shocks and cash-on-hand.

The two other panels of Figure 1 refer to the distribution of the wealth effect with respect to age, again grouped in 20 equally sized bins. For positive shocks, the correlation between age and the wealth effect is positive, so that moving from the youngest to the oldest cohorts, the wealth effect increases from about 2 to 6 cents per euro. Again, for negative shocks we find essentially no relation between age and the wealth effect.

\subsection{Regression results}

Table 2 reports average marginal effects from probit models for the probability of making a consumption adjustment following positive and negative shocks equal to $10 \%$ of one's home value (i.e., the extensive margin decision). The specification in column (1) includes quartiles of cash-on-hand, as well as age, gender, family size, and dummies for high school and college education.

The probability of reporting a positive wealth effect declines quite significantly with cash-on-hand, particularly at low levels of cash-on-hand. A move from the first quartile (the excluded category) to the third quartile of the cash-on-hand distribution is associated with a

\footnotetext{
22 Therefore, low cash-on-hand households in our data include both those who have low net worth as well as those who are "wealthy hand-to-mouth", as defined by Kaplan and Violante (2014). Households of the latter type might have a large amount of illiquid assets (such as a house) but low levels of (liquid) financial assets.
} 
reduction of the probability of 3.9 percentage points, while a move to the fourth quartile reduces the probability by 10 percentage points. One explanation for the negative correlation between the wealth effect and cash-on-hand is that low cash-on-hand households are much more likely to sell the house after the positive shock (26\%) compared to those with cash-on-hand above the median (10\%). The negative correlation also suggests that credit markets are an important channel linking wealth shocks to consumption. Indeed, 32\% of households with cash-on-hand below the median report that they would top up the mortgage after the positive shock, against $20 \%$ among those with cash-on-hand above the median.

Next, we examine the role of indebtedness by associating consumption responses to wealth shocks with the LTV. In the Netherlands a 100\% LTV represents an important indebtedness threshold for several reasons. First, applications for new mortgage debt are subject to a legal LTV cap of 100\%; many first-time homebuyers take out mortgages at or close to this capped value. Second, when households with high mortgage debt go underwater (due to declining house prices), the cost of their debt increases when moving to a new house or refinancing the mortgage. This is partly because the tax code does not allow mortgage interest rate deductions for the part of the mortgage loan exceeding the home value, and partly because mortgage interest rates on loans with an LTV higher than 100\% face a surcharge. Moreover, higher mortgage payments reduce access to consumer credit. Finally, if an important vehicle for financing a wealth effect on consumption is equity extraction through home equity loans, an LTV of $100 \%$ or more implies there is no equity to extract in the first place (at least for younger homeowners), and hence a lower or no consumption response (no wealth effect) would not be surprising.

In view of the above, we check whether relaxing a (likely) binding liquidity constraint affects the probability of increasing consumption after a positive shock. To this end, we use a dummy for households with a loan-to-value ratio (LTV) between 100 and 110\%, since for these 
households a $10 \%$ house price increase will lower their LTV ratio below $100 \%$, with potential liquidity benefits. ${ }^{23}$ On the other hand, such a house price increase will not relax the liquidity constraint that households with LTV in excess of $110 \%$ presently face. According to results shown in column (2) of Table 2, we find that only the former group plans to increase consumption in response to a positive shock.

The counterpart specifications for negative shocks are reported in columns (3) and (4) of Table 2. The wealth effect is again higher in the lower quartiles of cash-on-hand, showing that a move from the first to the third quartile of cash-on-hand increases the probability of a negative consumption adjustment by 7.0 percentage points (9.5 percentage points for a move to the fourth quartile). Like in the case of positive shocks, we use dummies denoting households for which a $10 \%$ house price decrease implies either the onset of a liquidity constraint (i.e. an LTV between 90 and 100\%) or further tightening of a current liquidity constraint (i.e. an LTV in excess of $100 \%)$. We find that both groups plan to reduce spending in the face of a negative shock, as an LTV higher than $100 \%$ impairs access to credit. Specifically, we find that, in case of a negative shock, the probability of a consumption adjustment is 7 and 9 percentage points higher for these two groups of households. In sum, results from specifications that account for LTVs suggest that households respond to liquidity constraints and the relevant thresholds set by the institutional environment.

We complement the analysis above by also estimating Tobit regressions. Specifically, we model the response of the wealth effect (which is censored at 0 and 1) to the two shocks, controlling for the socio-economic characteristics used above. In Table 3 we report the corresponding average marginal effects, conditional on the wealth effect being uncensored. Results are similar to those discussed for the probit estimates, suggesting that a similar set of

\footnotetext{
${ }^{23}$ Due to missing values for the LTV ratio, the samples in columns (2) and (4) are slightly reduced. We also experiment with a richer specification that includes dummies for LTV thresholds below 100\%, such as 50\% and $70 \%$ and we did not find any statistically significant differences in responses for these groups.
} 
characteristics contributes to both the intensive and extensive margin response of consumption to the two shocks.

\subsection{Robustness checks}

Cash-on-hand is defined as current net household income plus net financial wealth. In additional regressions we check whether income and cash-on-hand have a different effect on the probability of making a consumption adjustment and on the reported size of the wealth effect on consumption. For this purpose, we use separate dummies for household net income and net financial wealth quartiles.

Arguably, the consumption response to house price shocks might depend on the size of the shock itself, which by construction is proportional to the value of the house. Thus, in additional specifications, we also check whether the house value matters by controlling for housing wealth quartiles. The results suggest that the main driver of the wealth effects is net financial wealth. Net income plays essentially no role, as the income quartile dummies are never statistically significant. Coefficients of the dummies for real assets are also mostly insignificant. These additional results are reported in the online Appendix, Tables A1 and A2.

As discussed, presenting the same shock scenarios to survey respondents implies that the underlying shock is not correlated with household characteristics and behavioural traits. As a result, responses to the survey questions should be insensitive to variables reflecting individuals' general optimism, understanding of the survey questions, and expectations about future housing price shocks (aggregate or idiosyncratic). To examine this, we exploit the richness of our data and add to our baseline specifications indicators of the above characteristics.

First, we construct an indicator of optimism by taking the difference between subjective life expectancy (i.e., self-reported probability to survive upon age 65, 80 or 90, depending on 
the current age) and objective life expectancy (by gender and age) from official mortality tables. ${ }^{24}$ Second, since survey responses may be affected by financial sophistication, we control explicitly for respondents’ financial literacy. ${ }^{25}$ Further, we check if expectations about future house prices affect the wealth effect. To this end, we utilize respondents' expectations about aggregate price movements in the Dutch housing market ${ }^{26}$ as well as expectations about house prices in their own neighbourhood (which clearly have a large idiosyncratic component). As mentioned earlier, these expectations are calculated using a special set of questions that elicit, for each respondent, the first and second moments of the expected distribution of house prices. We find that our baseline estimates are insensitive to proxies for optimism, financial sophistication as well as expectations about future aggregate or idiosyncratic house price fluctuations.

In addition, we check whether the housing wealth effect on consumption is related to bequest motives by constructing a variable that takes into account both the probability of making a bequest as well as the planned amount. ${ }^{27}$ We find that the coefficient of planned bequests (standardized by total cash-on-hand) is negative, but statistically insignificant. Finally, we find that results are also unaffected if we control for a dummy denoting planning to move. Further, results are similar if we replace cash-on-hand quartile dummies with log cash-on-hand or the deciles (or ventiles) of the cash-on-hand distribution.

\section{Summary}

\footnotetext{
${ }^{24}$ Puri and Robinson (2007) use a similar measure of optimism.

${ }^{25}$ We proxy financial literacy by the number of correct answers out of the three basic questions measuring financial knowledge developed by Lusardi and Mitchell (2011).

26 The relevant information is collected in the baseline DNB survey (contacted few months prior to our specialpurpose survey) and asks respondents to indicate the kind of price movements they expect on the housing market in general in the next two years.

${ }^{27}$ We ask households to report the probabilities that they will leave an inheritance of: (i) $€ 10,000$ or more; (ii) $€ 100,000$ or more; and (iii) $€ 500,000$ or more. Based on reported probabilities to these questions we deduce a measure of planned bequest for each respondent.
} 
We use the responses of a representative sample of Dutch households to survey questions that ask how much their consumption would change due to unexpected, permanent shocks (positive or negative) to their house value. By design, these shocks are orthogonal to observable and unobservable household characteristics. Our survey questions elicit in a simple and effective way respondent-specific consumption response to a given change in home value (the wealth effect). Thus, we avoid the issue of estimating the wealth effect using observed comovements of spending and home prices, which may not necessarily reveal the causal effect of home value changes on consumption. Moreover, our approach allows measuring heterogeneous wealth effects and studying their association with household characteristics. In addition, we test for asymmetric responses to positive and negative wealth shocks without relying on selected household groups exposed to one of the two types of shock.

The average effect on consumption that we calculate out of individual reported responses to a change in the value of their house is in the range of 2 to 5 cents per euro, in line with econometric estimates that use wealth and consumption realizations. However, the respondentspecific wealth effects uncover significant heterogeneity of spending responses. In particular, the extensive margin response is limited, with more than $90 \%$ of the sample not responding to positive or negative housing wealth shocks. This represents a novel finding in the literature on the consumption response to housing wealth shock. On the other hand, intensive margin responses are large. Conditioning on adjusting their consumption, households report significant consumption adjustments. The relation between the wealth effect on consumption and cashon-hand is negative, consistent with models with precautionary saving and liquidity constraints. In a related vein, homeowners that are underwater reduce consumption significantly when hit by a negative housing wealth shock. We also find that adjustments in savings represent the main channel through which consumption responds to housing wealth shocks. Finally, we find evidence for asymmetric wealth effects. That is, the consumption 
response to positive wealth shocks is greater than the response to negative shocks, as suggested by the collateral channel mechanism of transmission between wealth shocks and consumption.

Overall, our approach provides not only a methodological alternative to existing studies investigating the links between housing wealth shocks and consumption adjustments, but also reveals important elements of response heterogeneity that may be useful when considering the effect of housing policies. 


\section{References}

Aladangady, A. (2017), "Housing wealth and consumption: evidence from geographically linked microdata”, American Economic Review 107, 3415-3446.Attanasio, Orazio P., Laura Blow, Robert Hamilton, and Andrew Leicester. 2009. "Booms and busts: Consumption, house prices and expectations,” Economica 76, 20-50.

Andersen, H. Y., and S. Leth-Petersen (2020), "Housing wealth or collateral: how home value shocks drive home equity extraction and spending," Journal of the European Economic Association , https://doi.org/10.1093/jeea/jvz083 .

Beraja, M., A. Fuster, E. Hurst, and J. Vavra (2019), "Regional heterogeneity and the refinancing channel of monetary policy,” The Quarterly Journal of Economics 134, 109183.

Berger, D., V. Guerrieri, G. Lorenzoni, and J. Vavra (2018), "House prices and consumer spending,” The Review of Economic Studies 85, 1502-1542.

Bunn, P., Le Roux, J., Reinold, K. and Surico (2018), “The consumption response to positive and negative income shocks”, Journal of Monetary Economics 96, 1-15.

Campbell, J., Cocco, J. (2007), "How do house prices affect consumption? Evidence from micro data”, Journal of Monetary Economics 54, 591-621.

Carroll, C., Slacalek, J., Otsuka, M. (2011), “How large are housing and financial wealth effects? A new approach”, Journal of Money, Credit and Banking 43, 55-79.

Christelis, D., Georgarakos, D., Jappelli, T. (2015), “Wealth shocks, unemployment shocks and consumption in the wake of the Great Recession”, Journal of Monetary Economics 72, 21-41. 
Christelis, D., Georgarakos, D., Jappelli, T., Pistaferri L., van Rooij, M. (2019), “Asymmetric consumption effects of transitory income shocks”, The Economic Journal 129, 23222341.

Contreras, J., Nichols J. (2010), “Consumption responses to permanent and transitory shocks to house appreciation”, Federal Reserve Board Finance and Economics Discussion Papers 2010-2032.

Disney, R., Gathergood, J., Henley, A. (2010), “House price shocks, negative equity and household consumption in the United Kingdom”, Journal of the European Economic Association 8, 1179-1207.

Dynan, Karen E., and Dean M. Maki (2001), “Does stock market wealth matter for consumption?” Finance and Economics Discussion Series 2001-23, Board of Governors of the Federal Reserve System.

Fuster, A., Kaplan, G., Zafar, B. (2018), “What would you do with \$500? Spending responses to gains, losses, news and loans”, National Bureau of Economic Research, Working Paper No. 24386.

Graziani, G., van der Klaauw, W., Zafar, B. (2016) “Workers’ spending response to the 2011 payroll tax cuts”, American Economic Journal: Economic Policy 8(4), 124-59

Guiso, L. Jappelli, T., Pistaferri, L. (2002) “An empirical analysis of earnings and employment risk”, Journal of Business and Economic Statistics 20(2), 241-253.

Jappelli, T., Pistaferri, L. (2011), “The consumption response to income changes”, Annual Review of Economics 2, 479-506.

Jappelli, T., Pistaferri, L. (2014), “Fiscal policy and MPC heterogeneity”, American Economic Journal: Macroeconomics 6, 107-36. 
Jappelli, T., Pistaferri, L. (2017), The Economics of Consumption. Oxford: Oxford University Press.

Jappelli, T., Pistaferri, L. (2020), “Reported MPC and unobserved heterogeneity,” American Economic Journal: Economic Policy (forthcoming).

Ji, K. Teulings, R., Wouterse, B. (2019), "Disentangling the effect of household debt on consumption”, Netherlands Bureau of Economic Analysis, Discussion Paper.

Hryshko, D., Luengo-Prado, M., Sorensen, B. (2010), “House prices and risk sharing”, Journal of Monetary Economics 57, 975-987.

Ludwig, A., Sløk, T. (2004), “The relationship between stock prices, house prices, and consumption in OECD countries”, The B.E. Journal of Macroeconomics 4, 1-28.

Lusardi, A., Mitchell, O. (2011), “Financial literacy around the world: An overview,” Journal of Pension Economics and Finance 10, 497-508.

Manski, C. F. (2017), “Survey of measurement of probabilistic macroeconomic expectations: progress and promise”, NBER Macroeconomics Annual 2017, vol. 32, edited by Martin Eichenbaum and Jonathan A. Parker, 411-471. Chicago, IL: University of Chicago Press..

Mian, A., K. Rao, and A. Sufi (2013), "Household balance sheets, consumption, and the economic slump,” The Quarterly Journal of Economics 128, 1687-1726.

Kaplan G., Violante, G.L. (2014), “A model of the consumption response to fiscal stimulus payments”, Econometrica 82, 1199-1239.

Paiella, M., Pistaferri, L. (2017), “Decomposing the wealth effect on consumption”, The Review of Economics and Statistics 99, 710-721.

Puri, M., and D. Robinson (2007), “Optimism and economic choice,” Journal of Financial Economics 86, 71-99. 
Shapiro, M.D., Slemrod, J. (1995), “Consumer response to the timing of income: evidence from a change in tax withholding”, American Economic Review 85, 274-283.

Shapiro, M.D., Slemrod, J. (2003), “Did the 2001 tax rebate stimulate spending? Evidence from taxpayer surveys”, in J.M. Poterba, ed., Tax Policy and the Economy 17, 83-109. Cambridge: MIT Press. 
Table 1

Sample statistics

\begin{tabular}{l|ccccc}
\hline & Mean & S.D. & Median & $95^{\text {th }} p c t$ & $N$ \\
\hline Fraction reporting positive $\Delta \mathrm{C}$ from positive $\Delta \mathrm{W}$ & 0.084 & 0.278 & 0.000 & 1.000 & 1,069 \\
Fraction reporting negative $\Delta \mathrm{C}$ from negative $\Delta \mathrm{W}$ & 0.094 & 0.293 & 0.000 & 1.000 & 974 \\
Wealth effect out of positive $\Delta \mathrm{W}$ & 0.047 & 0.190 & 0.000 & 0.412 & 1,069 \\
Wealth effect out of negative $\Delta \mathrm{W}$ & 0.021 & 0.116 & 0.000 & 0.068 & 974 \\
Age & 52.5 & 15.3 & 53.0 & 77.0 & 1,264 \\
Female & 0.434 & 0.496 & 0.000 & 1.000 & 1,264 \\
Family size & 2.341 & 1.183 & 2.000 & 5.000 & 1,264 \\
High school & 0.353 & 0.478 & 0.000 & 1.000 & 1,263 \\
College & 0.409 & 0.492 & 0.000 & 1.000 & 1,263 \\
Cash-on-hand & 79,314 & 170,269 & 32,375 & 303,900 & 1,136 \\
$100 \%<\mathrm{LTV}<110 \%$ & 0.039 & 0.193 & 0.000 & 0.000 & 1,192 \\
LTV $>110 \%$ & & & & & \\
90\% $<$ LTV $<100 \%$ & 0.040 & 0.195 & 0.000 & 0.000 & 1,192 \\
LTV $>100 \%$ & 0.099 & 0.299 & 0.000 & 1.000 & 1,192 \\
\hline & 0.065 & 0.247 & 0.000 & 1.000 & 1,192 \\
\hline
\end{tabular}

Note. Cash-on-hand is expressed in thousand euro. 
Table 2

Probit regressions for the determinants of the probability of wealth effects

\begin{tabular}{|c|c|c|c|c|}
\hline \multirow[b]{2}{*}{ Age } & \multicolumn{2}{|c|}{ Positive wealth shock } & \multicolumn{2}{|c|}{ Negative wealth shock } \\
\hline & $\begin{array}{c}0.001 \\
(0.001)\end{array}$ & $\begin{array}{c}0.001 \\
(0.001)^{* *}\end{array}$ & $\begin{array}{l}-0.001 \\
(0.001)\end{array}$ & $\begin{array}{l}-0.000 \\
(0.001)\end{array}$ \\
\hline Female & $\begin{array}{c}0.002 \\
(0.018)\end{array}$ & $\begin{array}{c}0.008 \\
(0.018)\end{array}$ & $\begin{array}{l}-0.016 \\
(0.020)\end{array}$ & $\begin{array}{l}-0.010 \\
(0.019)\end{array}$ \\
\hline Family size & $\begin{array}{l}-0.013 \\
(0.009)\end{array}$ & $\begin{array}{l}-0.010 \\
(0.009)\end{array}$ & $\begin{array}{l}-0.021 \\
(0.010)^{* *}\end{array}$ & $\begin{array}{l}-0.023 \\
(0.010)^{* *}\end{array}$ \\
\hline High school & $\begin{array}{l}-0.022 \\
(0.023)\end{array}$ & $\begin{array}{l}-0.029 \\
(0.022)\end{array}$ & $\begin{array}{l}-0.046 \\
(0.029)\end{array}$ & $\begin{array}{l}-0.050 \\
(0.029)^{*}\end{array}$ \\
\hline College & $\begin{array}{l}-0.029 \\
(0.022)\end{array}$ & $\begin{array}{l}-0.036 \\
(0.022)\end{array}$ & $\begin{array}{c}0.003 \\
(0.026)\end{array}$ & $\begin{array}{l}-0.000 \\
(0.026)\end{array}$ \\
\hline II cash-on-hand quartile & $\begin{array}{l}-0.038 \\
(0.023)^{*}\end{array}$ & $\begin{array}{l}-0.032 \\
(0.023)\end{array}$ & $\begin{array}{l}-0.041 \\
(0.025)\end{array}$ & $\begin{array}{l}-0.036 \\
(0.025)\end{array}$ \\
\hline III cash-on-hand quartile & $\begin{array}{l}-0.039 \\
(0.023)^{*}\end{array}$ & $\begin{array}{l}-0.029 \\
(0.023)\end{array}$ & $\begin{array}{l}-0.070 \\
(0.027)^{* *}\end{array}$ & $\begin{array}{l}-0.059 \\
(0.028)^{* *}\end{array}$ \\
\hline IV cash-on-hand quartile & $\begin{array}{l}-0.100 \\
(0.029)^{* * *}\end{array}$ & $\begin{array}{l}-0.083 \\
(0.028)^{* * *}\end{array}$ & $\begin{array}{l}-0.095 \\
(0.030)^{* * *}\end{array}$ & $\begin{array}{l}-0.082 \\
(0.030)^{* * *}\end{array}$ \\
\hline $100 \%<\mathrm{LTV}<110 \%$ & & $\begin{array}{l}0.103 \\
(0.038)^{* * *}\end{array}$ & & \\
\hline LTV > 110\% & & $\begin{array}{c}0.062 \\
(0.041)\end{array}$ & & \\
\hline $90 \%<$ LTV $<100 \%$ & & & & $\begin{array}{l}0.070 \\
(0.034)^{* *}\end{array}$ \\
\hline LTV > 100\% & & & & $\begin{array}{l}0.093 \\
(0.037)^{* *}\end{array}$ \\
\hline $\mathrm{N}$ & 980 & 958 & 906 & 895 \\
\hline
\end{tabular}

Note. Average marginal effects from probit estimates (robust standard errors clustered by household in parentheses). LTV dummies distinguish among groups with different implications for their indebtedness due to wealth shocks. In the positive wealth shock regression, LTV dummies equal one if LTV is between 100 and $110 \%$ and if LTV exceeds $110 \%$. In the negative wealth shock regression, LTV dummies equal one if LTV is between 90 and $100 \%$ and if LTV exceeds $100 \%$. Stars indicate significance at the 1,5 and 10 percent levels, respectively. 
Table 3

Tobit regressions for the determinants of the wealth effects

\begin{tabular}{|c|c|c|c|c|}
\hline \multirow[b]{2}{*}{ Age } & \multicolumn{2}{|c|}{ Positive wealth shock } & \multicolumn{2}{|c|}{ Negative wealth shock } \\
\hline & $\begin{array}{c}0.001 \\
(0.000)\end{array}$ & $\begin{array}{l}0.001 \\
(0.000)^{* *}\end{array}$ & $\begin{array}{l}-0.000 \\
(0.000)\end{array}$ & $\begin{array}{c}0.000 \\
(0.000)\end{array}$ \\
\hline Female & $\begin{array}{c}0.000 \\
(0.012)\end{array}$ & $\begin{array}{c}0.005 \\
(0.011)\end{array}$ & $\begin{array}{l}-0.006 \\
(0.007)\end{array}$ & $\begin{array}{l}-0.004 \\
(0.006)\end{array}$ \\
\hline Family size & $\begin{array}{l}-0.010 \\
(0.006)^{*}\end{array}$ & $\begin{array}{l}-0.007 \\
(0.006)\end{array}$ & $\begin{array}{l}-0.007 \\
(0.004)^{*}\end{array}$ & $\begin{array}{l}-0.007 \\
(0.004)^{* *}\end{array}$ \\
\hline High school & $\begin{array}{l}-0.013 \\
(0.015)\end{array}$ & $\begin{array}{l}-0.020 \\
(0.014)\end{array}$ & $\begin{array}{l}-0.009 \\
(0.009)\end{array}$ & $\begin{array}{l}-0.010 \\
(0.009)\end{array}$ \\
\hline College & $\begin{array}{l}-0.020 \\
(0.015)\end{array}$ & $\begin{array}{l}-0.025 \\
(0.015)^{*}\end{array}$ & $\begin{array}{c}0.005 \\
(0.008)\end{array}$ & $\begin{array}{c}0.003 \\
(0.008)\end{array}$ \\
\hline II cash-on-hand quartile & $\begin{array}{l}-0.029 \\
(0.016)^{*}\end{array}$ & $\begin{array}{l}-0.023 \\
(0.016)\end{array}$ & $\begin{array}{l}-0.009 \\
(0.008)\end{array}$ & $\begin{array}{l}-0.008 \\
(0.008)\end{array}$ \\
\hline III cash-on-hand quartile & $\begin{array}{l}-0.029 \\
(0.015)^{*}\end{array}$ & $\begin{array}{l}-0.021 \\
(0.015)\end{array}$ & $\begin{array}{l}-0.018 \\
(0.009)^{* *}\end{array}$ & $\begin{array}{l}-0.014 \\
(0.009)\end{array}$ \\
\hline IV cash-on-hand quartile & $\begin{array}{l}-0.069 \\
(0.020)^{* * *}\end{array}$ & $\begin{array}{l}-0.056 \\
(0.019)^{* * *}\end{array}$ & $\begin{array}{l}-0.030 \\
(0.011)^{* * *}\end{array}$ & $\begin{array}{l}-0.026 \\
(0.010)^{* *}\end{array}$ \\
\hline $100 \%<\mathrm{LTV}<110 \%$ & & $\begin{array}{l}0.073 \\
(0.026)^{* * *}\end{array}$ & & \\
\hline LTV > 110\% & & $\begin{array}{c}0.043 \\
(0.027)\end{array}$ & & \\
\hline $90 \%<\mathrm{LTV}<100 \%$ & & & & $\begin{array}{c}0.021 \\
(0.011)^{*}\end{array}$ \\
\hline LTV > 100\% & & & & $\begin{array}{l}0.024 \\
(0.011)^{* *}\end{array}$ \\
\hline $\mathrm{N}$ & 980 & 958 & 906 & 895 \\
\hline
\end{tabular}

Note. Average marginal effects from tobit estimates, censored at 0 and 1 (robust standard errors clustered by household in parentheses). LTV dummies distinguish among groups with different implications for their indebtedness due to wealth shocks. In the positive wealth shock regression, LTV dummies equal one if LTV is between 100 and $110 \%$ and if LTV exceeds $110 \%$. In the negative wealth shock regression, LTV dummies equal one if LTV is between 90 and $100 \%$ and if LTV exceeds 100\%. Stars indicate significance at the 1, 5 and 10 percent levels, respectively. 
Figure 1

The relation between the wealth effect, age and cash-on-hand
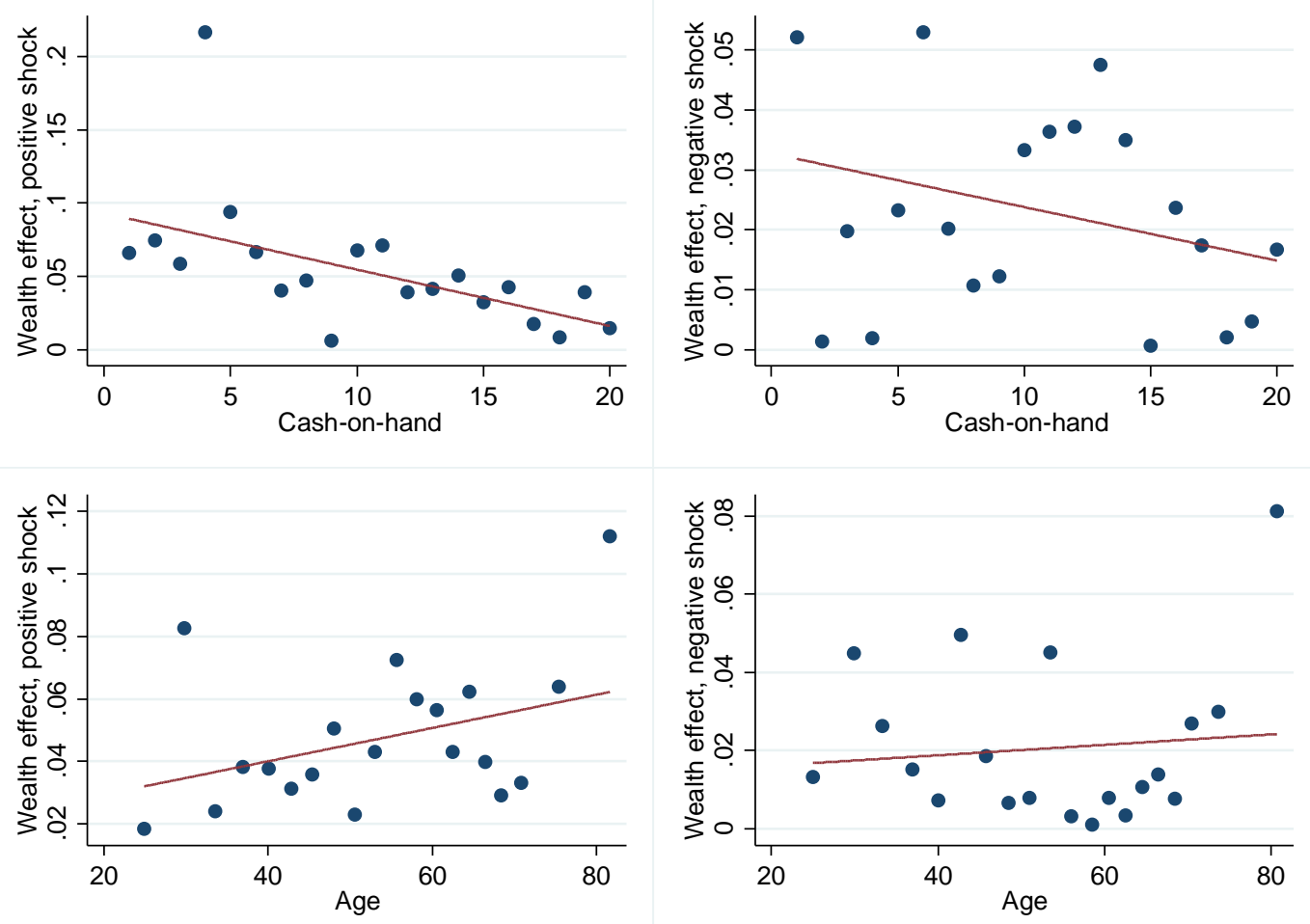


\section{Appendix}

Table A1

Probit regressions for the determinants of the probability of wealth effects

\begin{tabular}{|c|c|c|c|c|c|c|}
\hline \multirow[b]{2}{*}{ Age } & \multicolumn{3}{|c|}{ Positive wealth shock } & \multicolumn{3}{|c|}{ Negative wealth shock } \\
\hline & $\begin{array}{c}0.001 \\
(0.001)\end{array}$ & $\begin{array}{c}0.001 \\
(0.001)^{*}\end{array}$ & $\begin{array}{c}0.001 \\
(0.001)\end{array}$ & $\begin{array}{l}-0.001 \\
(0.001)\end{array}$ & $\begin{array}{l}-0.000 \\
(0.001)\end{array}$ & $\begin{array}{l}-0.001 \\
(0.001)\end{array}$ \\
\hline Female & $\begin{array}{c}0.001 \\
(0.018)\end{array}$ & $\begin{array}{c}0.007 \\
(0.018)\end{array}$ & $\begin{array}{c}0.000 \\
(0.018)\end{array}$ & $\begin{array}{l}-0.018 \\
(0.020)\end{array}$ & $\begin{array}{l}-0.013 \\
(0.020)\end{array}$ & $\begin{array}{l}-0.018 \\
(0.020)\end{array}$ \\
\hline Family size & $\begin{array}{l}-0.010 \\
(0.009)\end{array}$ & $\begin{array}{l}-0.006 \\
(0.009)\end{array}$ & $\begin{array}{l}-0.008 \\
(0.009)\end{array}$ & $\begin{array}{c}-0.019 \\
(0.011)^{*}\end{array}$ & $\begin{array}{c}-0.022 \\
(0.011)^{* *}\end{array}$ & $\begin{array}{c}-0.020 \\
(0.011)^{*}\end{array}$ \\
\hline High school & $\begin{array}{l}-0.019 \\
(0.023)\end{array}$ & $\begin{array}{l}-0.025 \\
(0.022)\end{array}$ & $\begin{array}{l}-0.019 \\
(0.023)\end{array}$ & $\begin{array}{l}-0.041 \\
(0.029)\end{array}$ & $\begin{array}{l}-0.044 \\
(0.028)\end{array}$ & $\begin{array}{l}-0.041 \\
(0.028)\end{array}$ \\
\hline College & $\begin{array}{l}-0.024 \\
(0.023)\end{array}$ & $\begin{array}{l}-0.029 \\
(0.023)\end{array}$ & $\begin{array}{l}-0.024 \\
(0.023)\end{array}$ & $\begin{array}{c}0.008 \\
(0.027)\end{array}$ & $\begin{array}{l}-0.005 \\
(0.027)\end{array}$ & $\begin{array}{c}0.007 \\
(0.027)\end{array}$ \\
\hline II net fin wealth qrt & $\begin{array}{l}-0.036 \\
(0.022)\end{array}$ & $\begin{array}{l}-0.029 \\
(0.023)\end{array}$ & $\begin{array}{l}-0.029 \\
(0.022)\end{array}$ & $\begin{array}{c}-0.040 \\
(0.024)^{*}\end{array}$ & $\begin{array}{l}-0.033 \\
(0.025)\end{array}$ & $\begin{array}{c}-0.040 \\
(0.024)^{*}\end{array}$ \\
\hline III net fin wealth qrt & $\begin{array}{l}-0.036 \\
(0.025)\end{array}$ & $\begin{array}{l}-0.025 \\
(0.025)\end{array}$ & $\begin{array}{l}-0.029 \\
(0.025)\end{array}$ & $\begin{array}{c}-0.063 \\
(0.029)^{* *}\end{array}$ & $\begin{array}{c}-0.051 \\
(0.029)^{*}\end{array}$ & $\begin{array}{c}-0.063 \\
(0.029)^{* *}\end{array}$ \\
\hline IV net fin wealth qrt & $\begin{array}{c}-0.089 \\
(0.028)^{* * *}\end{array}$ & $\begin{array}{c}-0.071 \\
(0.028)^{* *}\end{array}$ & $\begin{array}{c}-0.083 \\
(0.028)^{* * *}\end{array}$ & $\begin{array}{c}-0.102 \\
(0.030)^{* * *}\end{array}$ & $\begin{array}{c}-0.089 \\
(0.031)^{* * *}\end{array}$ & $\begin{array}{c}-0.102 \\
(0.030)^{* * *}\end{array}$ \\
\hline II net income qrt & $\begin{array}{l}-0.015 \\
(0.024)\end{array}$ & $\begin{array}{l}-0.017 \\
(0.023)\end{array}$ & $\begin{array}{l}-0.011 \\
(0.024)\end{array}$ & $\begin{array}{c}0.010 \\
(0.028)\end{array}$ & $\begin{array}{c}0.007 \\
(0.028)\end{array}$ & $\begin{array}{c}0.010 \\
(0.028)\end{array}$ \\
\hline III net income qrt & $\begin{array}{l}-0.018 \\
(0.026)\end{array}$ & $\begin{array}{l}-0.024 \\
(0.025)\end{array}$ & $\begin{array}{l}-0.013 \\
(0.026)\end{array}$ & $\begin{array}{l}-0.039 \\
(0.032)\end{array}$ & $\begin{array}{l}-0.040 \\
(0.032)\end{array}$ & $\begin{array}{l}-0.039 \\
(0.032)\end{array}$ \\
\hline IV net income qrt & $\begin{array}{l}-0.033 \\
(0.030)\end{array}$ & $\begin{array}{l}-0.041 \\
(0.031)\end{array}$ & $\begin{array}{l}-0.025 \\
(0.030)\end{array}$ & $\begin{array}{l}-0.003 \\
(0.033)\end{array}$ & $\begin{array}{l}-0.005 \\
(0.033)\end{array}$ & $\begin{array}{l}-0.002 \\
(0.033)\end{array}$ \\
\hline $100 \%<\mathrm{LTV}<110 \%$ & & $\begin{array}{c}0.110 \\
(0.038)^{* * *}\end{array}$ & & & & \\
\hline LTV $>110 \%$ & & $\begin{array}{c}0.062 \\
(0.041)\end{array}$ & & & & \\
\hline $90 \%<\mathrm{LTV}<100 \%$ & & & & & $\begin{array}{c}0.072 \\
(0.034)^{* * *}\end{array}$ & \\
\hline LTV > 100\% & & & & & $\begin{array}{c}0.092 \\
(0.037)^{* *}\end{array}$ & \\
\hline II house wealth qrt & & & $\begin{array}{l}-0.027 \\
(0.025)\end{array}$ & & & $\begin{array}{c}0.009 \\
(0.027)\end{array}$ \\
\hline III house wealth qrt & & & $\begin{array}{c}-0.048 \\
(0.024)^{* *}\end{array}$ & & & $\begin{array}{l}-0.002 \\
(0.027)\end{array}$ \\
\hline IV house wealth qrt & & & $\begin{array}{l}-0.009 \\
(0.025)\end{array}$ & & & $\begin{array}{c}0.004 \\
(0.028)\end{array}$ \\
\hline$N$ & 980 & 958 & 980 & 906 & 895 & 906 \\
\hline
\end{tabular}

Note. See note to Table 2. Average marginal effects from probit estimates (robust standard errors clustered by household in parentheses). Stars indicate significance at the 1, 5 and 10 percent levels. 
Table A2

Tobit regressions for the determinants of the wealth effects

\begin{tabular}{|c|c|c|c|c|c|c|}
\hline \multirow[b]{2}{*}{ Age } & \multicolumn{3}{|c|}{ Positive wealth shock } & \multicolumn{3}{|c|}{ Negative wealth shock } \\
\hline & $\begin{array}{c}0.001 \\
(0.000)\end{array}$ & $\begin{array}{c}0.001 \\
(0.000)^{* *}\end{array}$ & $\begin{array}{c}0.001 \\
(0.000)\end{array}$ & $\begin{array}{l}-0.000 \\
(0.000)\end{array}$ & $\begin{array}{c}0.000 \\
(0.000)\end{array}$ & $\begin{array}{l}-0.000 \\
(0.000)\end{array}$ \\
\hline Female & $\begin{array}{l}-0.001 \\
(0.012)\end{array}$ & $\begin{array}{c}0.004 \\
(0.011)\end{array}$ & $\begin{array}{l}-0.001 \\
(0.012)\end{array}$ & $\begin{array}{l}-0.007 \\
(0.007)\end{array}$ & $\begin{array}{l}-0.005 \\
(0.006)\end{array}$ & $\begin{array}{l}-0.007 \\
(0.007)\end{array}$ \\
\hline Family size & $\begin{array}{l}-0.007 \\
(0.006)\end{array}$ & $\begin{array}{l}-0.004 \\
(0.006)\end{array}$ & $\begin{array}{l}-0.006 \\
(0.006)\end{array}$ & $\begin{array}{l}-0.006 \\
(0.004)\end{array}$ & $\begin{array}{c}-0.007 \\
(0.004)^{*}\end{array}$ & $\begin{array}{c}-0.006 \\
(0.004)^{*}\end{array}$ \\
\hline High school & $\begin{array}{l}-0.012 \\
(0.015)\end{array}$ & $\begin{array}{l}-0.018 \\
(0.014)\end{array}$ & $\begin{array}{l}-0.012 \\
(0.015)\end{array}$ & $\begin{array}{l}-0.007 \\
(0.009)\end{array}$ & $\begin{array}{l}-0.008 \\
(0.009)\end{array}$ & $\begin{array}{l}-0.007 \\
(0.009)\end{array}$ \\
\hline College & $\begin{array}{l}-0.017 \\
(0.015)\end{array}$ & $\begin{array}{l}-0.021 \\
(0.015)\end{array}$ & $\begin{array}{l}-0.016 \\
(0.015)\end{array}$ & $\begin{array}{c}0.007 \\
(0.009)\end{array}$ & $\begin{array}{c}0.005 \\
(0.009)\end{array}$ & $\begin{array}{c}0.007 \\
(0.009)\end{array}$ \\
\hline II net fin wealth qrt & $\begin{array}{c}-0.026 \\
(0.015)^{*}\end{array}$ & $\begin{array}{l}-0.020 \\
(0.015)\end{array}$ & $\begin{array}{l}-0.021 \\
(0.015)\end{array}$ & $\begin{array}{l}-0.007 \\
(0.008)\end{array}$ & $\begin{array}{l}-0.006 \\
(0.008)\end{array}$ & $\begin{array}{l}-0.007 \\
(0.008)\end{array}$ \\
\hline III net fin wealth qrt & $\begin{array}{c}-0.030 \\
(0.016)^{*}\end{array}$ & $\begin{array}{c}-0.020 \\
(0.016)\end{array}$ & $\begin{array}{l}-0.024 \\
(0.016)\end{array}$ & $\begin{array}{c}-0.017 \\
(0.009)^{*}\end{array}$ & $\begin{array}{l}-0.013 \\
(0.009)\end{array}$ & $\begin{array}{l}-0.017^{*} \\
(0.009)\end{array}$ \\
\hline IV net fin wealth qrt & $\begin{array}{c}-0.061 \\
(0.019)^{* * * *}\end{array}$ & $\begin{array}{c}-0.047 \\
(0.019)^{* * * *}\end{array}$ & $\begin{array}{c}-0.056 \\
(0.019)^{* * *}\end{array}$ & $\begin{array}{c}-0.032 \\
(0.011)^{* * *}\end{array}$ & $\begin{array}{c}-0.028 \\
(0.011)^{* *}\end{array}$ & $\begin{array}{c}-0.032 \\
(0.011)^{* *}\end{array}$ \\
\hline II net income qrt & $\begin{array}{c}-0.014 \\
(0.016)\end{array}$ & $\begin{array}{l}-0.016 \\
(0.015)\end{array}$ & $\begin{array}{l}-0.011 \\
(0.015)\end{array}$ & $\begin{array}{c}0.002 \\
(0.009)\end{array}$ & $\begin{array}{c}0.002 \\
(0.009)\end{array}$ & $\begin{array}{c}0.002 \\
(0.009)\end{array}$ \\
\hline III net income qrt & $\begin{array}{l}-0.012 \\
(0.017)\end{array}$ & $\begin{array}{l}-0.016 \\
(0.016)\end{array}$ & $\begin{array}{l}-0.008 \\
(0.017)\end{array}$ & $\begin{array}{l}-0.013 \\
(0.011)\end{array}$ & $\begin{array}{l}-0.012 \\
(0.011)\end{array}$ & $\begin{array}{l}-0.013 \\
(0.011)\end{array}$ \\
\hline IV net income qrt & $\begin{array}{l}-0.023 \\
(0.020)\end{array}$ & $\begin{array}{l}-0.028 \\
(0.020)\end{array}$ & $\begin{array}{l}-0.015 \\
(0.020)\end{array}$ & $\begin{array}{l}-0.005 \\
(0.011)\end{array}$ & $\begin{array}{l}-0.004 \\
(0.011)\end{array}$ & $\begin{array}{l}-0.004 \\
(0.011)\end{array}$ \\
\hline $100 \%<\mathrm{LTV}<110 \%$ & & $\begin{array}{c}0.078 \\
(0.026)^{* * *}\end{array}$ & & & & \\
\hline LTV $>110 \%$ & & $\begin{array}{c}0.042 \\
(0.027)\end{array}$ & & & & \\
\hline $90 \%<\mathrm{LTV}<100 \%$ & & & & & $\begin{array}{c}0.022 \\
(0.011)^{* *}\end{array}$ & \\
\hline LTV > $100 \%$ & & & & & $\begin{array}{c}0.024 \\
(0.011)^{* *}\end{array}$ & \\
\hline II house wealth qrt & & & $\begin{array}{l}-0.019 \\
(0.016)\end{array}$ & & & $\begin{array}{c}0.005 \\
(0.009)\end{array}$ \\
\hline III house wealth qrt & & & $\begin{array}{c}-0.036 \\
(0.016)^{* *}\end{array}$ & & & $\begin{array}{c}0.002 \\
(0.009)\end{array}$ \\
\hline IV house wealth qrt & & & $\begin{array}{l}-0.013 \\
(0.016)\end{array}$ & & & $\begin{array}{l}-0.002 \\
(0.009)\end{array}$ \\
\hline$N$ & 980 & 958 & 980 & 906 & 895 & 906 \\
\hline
\end{tabular}

Note. See note to Table 3. Average marginal effects from tobit estimates, censored at 0 and 1 (robust standard errors clustered by household in parentheses). Stars indicate significance at the 1, 5 and 10 percent levels. 